\title{
Forcipomyia (Synthyridomyia) murina (Winnertz, 1852) in South America. Synonymy and redescription (Diptera: Ceratopogonidae)
}

\author{
Gustavo Ricardo Spinelli ${ }^{1} \&$ Pablo Ignacio Marino ${ }^{2}$ \\ ${ }^{1}$ Instituto de Limnología “Dr. Raúl A. Ringuelet" (ILPLA-CONICET), Boulevard 120 y 62 N 1437, \\ La Plata, Argentina. \\ ${ }^{2}$ División Entomología, Museo de La Plata, Paseo del Bosque s/n, La Plata, Argentina.
}

E-mail: spinelli@fcnym.unlp.edu.ar

\begin{abstract}
Both sexes of the hitherto Holarctic, Afrotropical and Oriental species Forcipomyia (Synthyridomyia) murina (Winnertz, 1852) are redescribed and the species is firstly recorded from Argentina (Salta, La Rioja, Santiago del Estero, Córdoba, Corrientes, Buenos Aires and Río Negro provinces). Forcipomyia (S.) calchaqui Spinelli \& Marino, 1997 and Forcipomyia (S.) soibelzoni Marino \& Spinelli, 2001 are recognized as its junior synonyms. A key for the identification of the four species of the subgenus that inhabit the Neotropical region is also presented, and F. murina is compared with the most similar Old World species.
\end{abstract}

Keywords: Forcipomyiinae, identification key, Neotropical, new record, synonymy.

Resumen. Se redescriben ambos sexos de la hasta ahora especie Holártica, Afrotropical y Oriental, Forcipomyia (Synthyridomyia) murina (Winnertz, 1852), y la especie se registra por primera vez en Argentina (provincias de Salta, La Rioja, Santiago del Estero, Córdoba, Corrientes, Buenos Aires y Río Negro). Forcipomyia (S.) calchaqui Spinelli \& Marino, 1997 y Forcipomyia (S.) soibelzoni Marino \& Spinelli, 2001 se reconocen como sinónimos menores. Se presenta una clave para la identificación de las cuatro especies del subgénero que habitan la región Neotropical, y se compara a F. murina con las especies más similares del Viejo Mundo.

Palabras Clave: Clave identificatoria, Forcipomyiinae, Neotropical, nueva cita, sinonimia.

\section{INTRODUCTION}

Biting midges of the genus Forcipomyia Meigen, 1818 inhabit all zoogeographical regions except Antarctica. They are very diverse and include 1154 extant and 32 extinct species (Borkent, 2016). Borkent \& Spinelli (2007) listed 211 Neotropical species of Forcipomyia, but 19 species were subsequently described or recorded from this region. The genus has considerable economic impact because many species are important pollinators of some commercial trees such as cacao (Theobroma cacao) and rubber (Hevea brasiliensis) (Borkent \& Spinelli, 2007).
Taxonomically, 36 subgenera are recognized within Forcipomyia (Borkent, 2016), and the current infrageneric classification is based mainly on adult morphology.

The subgenus Synthyridomyia Saunders, 1927 includes 27 extant and one extinct species worldwide (Borkent, 2016). Borkent \& Spinelli (2007) recorded four species for the Neotropical region, and Spinelli et al. (2010) assigned Forcipomyia calchaqui Spinelli \& Marino, 1997, a species originally described as Forcipomyia (Thyridomyia), to the subgenus Synthyridomyia, arising to five the number of Neotropical species of the subgenus. Of these, three species have been recorded from Argentina, F. (S.) calchaqui from Salta, La Rioja, Santiago del Estero, 
Córdoba and Buenos Aires, F. (S.) sanctaeclarae Wirth, 1952 from Juan Fernández islands, central Chile and Río Negro, Chubut and Santa Cruz provinces in Argentina, and F. (S.) soibelzoni Marino \& Spinelli, 2001 from the Argentinean province of Río Negro.

A recent study of the Forcipomyia from Argentina deposited in the collection of the Museo de La Plata, Argentina, revealed the presence of female specimens from several localities that were provisionally identified as F. (S.) calchaqui, being those from Buenos Aires and Salta provinces, including the type locality, associated with males. A close examination of the males and the comparison with the Old World species of the subgenus revealed that they actually belong to Forcipomyia (S.) murina (Winnertz, 1852), a species widely distributed in the Holarctic, Afrotropical and Oriental regions. This finding prompt us to record $F$. (S.) murina for the Neotropical region, to fully redescribe the species on the basis of the specimens from Argentina, and to propose $F$. (S.) calchaqui and $F$. (S.) soibelzoni as junior synonyms, after the examination of the type material of both species.

\section{MATERIAL AND METHODS}

Specimens were collected using CDC, Shannon or funnel light traps or Malaise traps in the great majority of the collecting localities, and sweeping along a narrow, meandrous stream in Alberti, Buenos Aires province. They were preserved in $70 \%$ ethanol and subsequently cleared, dissected and mounted on microscope slides in Canada balsam, and were examined and measured with a binocular compound microscope at 40-400X. Illustrations were made using an Olympus $\mathrm{CH} 2$ microscope with attached camera lucida. Photographs were taken with a Micrometrics SE Premium digital camera attached to a Nikon Eclipse E200 microscope.

Morphological terms follow those in the chapter on Ceratopogonidae in the recent Manual of Central American Diptera (Borkent et al., 2009). Special terms for the male genitalia are those provided by Alwin-Kownacka et al. (2016). Examined specimens are deposited in the Collection of the Museo de La Plata, Argentina (MLPA).

\section{SYSTEMATICS}

Key to Forcipomyia (Synthyridomyia) of the Neotropical region.

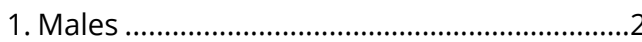

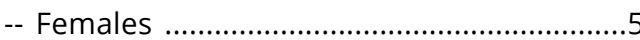

2. Posteromedian margin of sternite 9 straight or with shallow excavation; sensory pit of third palpal segment on prominent basal or mesal swelling. .3

-- Sternite 9 with very deep posteromedian excavation; sensory pit of third palpal segment on the slightly broader midportion

.... (S.) sanctaeclarae

3. Aedeagus with a dorsal, long, heavily sclerotized median projection with pointed tip curved mesad, and two pairs of posteriorly directed lateral sclerites; submedian process of parameres rod-like with apex not expanded .F. (S.) murina

-- Aedeagus without median projection, and with one pair of posteriorly directed lateral sclerites; submedian process of parameres rod-like with expanded apex

.4

4. Aedeagus with distal piece of lateral sclerite heavily sclerotized, blackish, with blunt tip.

F. (S.) floridensis

-- Aedeagus with distal piece of lateral sclerite moderately sclerotized, brownish, with sharp, slender tip F. (S.) tenuiforceps

5. Sensory pit of third palpal segment on prominent basal or mesal swelling; mandible with more than 20 teeth 6

-- Sensory pit of third palpal segment on the slightly broader midportion; mandible with approximately 12 minute teeth F. (S.) sanctaeclarae

6. Spermatheca with prominent, oblique neck 7

-- Spermatheca with short, scarcely apparent neck F. (S.) tenuiforceps

7. Sensory pit of third palpal segment on prominent basal swelling; flagellomeres 2-8 elongate, subcylindrical.. F. (S.) murina

-- Sensory pit of third palpal segment on prominent mesal swelling; flagellomeres 2-8 short, globose F. (S.) floridensis 
Synthyridomyia Saunders

Synthyridomyia Saunders, 1957: 688 (as subgenus of Forcipomyia). Type species: Lasiohelea acidicola Tokunaga, by original designation.

Forcipomyia (Synthyridomyia) murina (Winnertz) (Figures 1-11)

Ceratopogon murinus Winnertz, 1852: 26 (male, female, Germany).

Apelma aurosparsum Kieffer, 1919: 65 (male, Hungary).

Forcipomyia sulfurea Kieffer, 1923: 664 (female, Algeria).

Forcipomyia hirtipalpis Kieffer, 1924: 392 (male, France).

Forcipomyia sate Kieffer, 1925: 245 (male, female, Egypt).

Forcipomyia longitarsis Tokunaga, 1940: 92 (male, Taiwan).

Forcipomyia moascari Macfie, 1943: 147 (male, female, Egypt).

Forcipomyia attonsa Goetghebuer, 1950: 1 (male, Belgium).

Forcipomyia murina: Dow and Wirth 1972: 197 (male, female, North America, Europe =

Forcipomyia moascari Macfie, 1943, distribution); Remm, 1981: 31 (= Apelma aurosparsum Kieffer, 1919, Forcipomyia moascari Macfie, 1943); Szadziewski 1983: 379 (Algeria = Forcipomyia sulfurea Kieffer, 1923, Forcipomyia hirtipalpis Kieffer, 1924, Forcipomyia sate Kieffer, 1925); Szadziewski 1986: 21 (male, Belgium, = Forcipomyia longitarsis Tokunaga, 1940, Forcipomyia attonsa Goetghebuer, 1950, Forcipomyia murina sibmurina Remm, 1980); Boorman \& van Harten 2002: 438 (male, female, Bahrain, Oman, Yemen); Szadziewski et al. 2011: 639 (male, UAE); Alwin \& Szadziewski, 2013: 124 (photo male genitalia); Alwin-Kownacka et al., 2016: 371 (diagnosis, Israel, Yemen, distribution); Yu et al., 2005: 660 (male, Taiwan).

Forcipomyia murina sibmurina Remm, 1980: 115 (male, female, southern Siberia).

Forcipomyia calchaqui Spinelli \& Marino, 1997: 188 (female, Argentina); Spinelli et al., 2010: 130 (subgeneric position, Argentina records). NEW SYNONYM.

Forcipomyia soibelzoni Marino \& Spinelli, 2001: 14 (female, Argentina); Muzón et al., 2005: 62 (Argentina records). NEW SYNONYM.
DIAGNOSIS. Male. Only species of Neotropical Forcipomyia (Synthyridomyia) with posteromedian margin of sternite 9 straight, aedeagus with a dorsal heavily sclerotized median projection and two pairs of posteriorly directed lateral sclerites, and submedian process of parameres with not expanded apex. Female: only species of Neotropical Forcipomyia (Synthyridomyia) with sensory pit of third palpal segment on prominent basal swelling, and spermatheca with prominent, oblique neck.

Male. (Figures 1-5, 10-11). Head (Figure 1) brown. Eyes without interommatidial spicules. Antenna (Figure 1) with well developed plume, extending to base of flagellomere 13, flagellomeres 2-6 spherical, 7-9 vasiform, 10 cylindrical, greatly elongate, $1.90-2.10(2.00, n=3)$ $x$ longer than 11, 12 similar to 11 but shorter, 13 conical, slightly longer than 12 with apical nipple, slightly constricted basally; antennal ratio 0.95-1.09 (1.00, n=3). Palpus (Figure 2) with third segment elongate, with rounded, subbasal pit; segments 4, 5 separate, 5 distinctly shorter than 4; palpal ratio 3.70-4.10 (3.95, n=3). Thorax brown; scutellum paler, with 12 large, 6 smaller setae. Legs light brown; prothoracic tarsal ratio $2.50-2.70(2.63, n=3)$; mesothoracic tarsal ratio $2.20-2.40(2.35, n=3)$, metathoracic tarsal ratio $2.06-2.12(2.10, \mathrm{n}=3)$; tarsal claws well developed, apices simple. Wing (Figure 3) membrane pale, covered with macrotrichia; base of $\mathrm{M}_{2}$ not visible; 1 st radial cell obliterated, 2nd radial cell well developed; cubital fork distal to level of apex of costa; wing length 1.04-1.20 (1.10, $\mathrm{n}=3) \mathrm{mm}$, breadth 0.32-0.38 (0.35, $\mathrm{n}=3) \mathrm{mm}$; costal ratio $0.38-0.40$ (0.39, $\mathrm{n}=3)$. Halter whitish.

Abdomen pale brown. Genitalia (Figures 4-5, 10-11) brown: tergite 9 (Figure 4) short, extending to $1 / 2$ length of gonocoxite, posterior margin rounded with long, slender, setose, mesally directed apicolateral processes. Sternite 9 (Figure 5) as long as broad, posteromedian margin straight. Gonocoxite cylindrical, twice longer than greatest breadth; gonostylus 0.9 length of gonocoxite, broad basally, distal 2/3 slender, tip blunt. Parameres (Figures 4, 10) with angular basimedian processes nearly meeting on midline, each with lateral process bearing a slender, anteriorly directed knob and articulated with gonocoxal apodeme, submedian process 

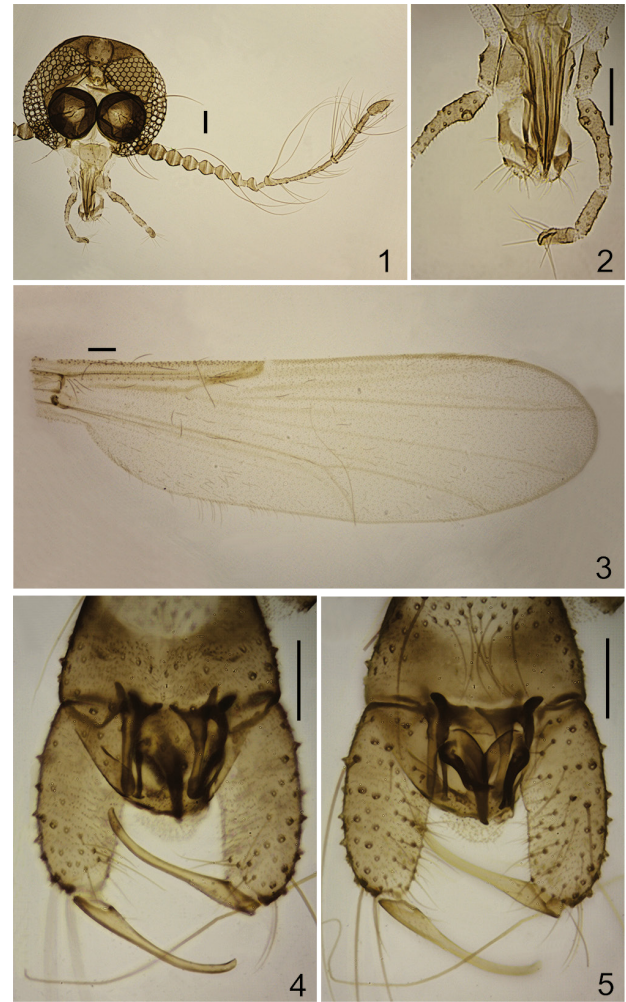

Figures 1-5. Forcipomyia (Synthyridomyia) murina (Winnertz). Male. 1: Head. 2: Palpus. 3: Wing. 4: Genitalia, dorsal view. 5: Genitalia, ventral view. Scale bars: $0.05 \mathrm{~mm}$.

stout, rod-like, fused with lateral process, apex not expanded. Aedeagus (Figures. 5, 11) complicated; basal arch reduced to a stout transverse basal bridge convex posteriorly, bearing on each end, a short, stout, posteriorly directed lateral arms, the mesal distal margins of which are expanded mesally in a broad posteroventrally curved plate with pointed tip curved mesad; from the caudal margin of each lateral arm articulates a slender, posteriorly directed sclerite, from which arises a stout, sinuous, heavily sclerotized, posteromesally directed sclerite with pointed tip.

Female (Figures 6-9). Head (Fig. 6) brown. Eyes abutting medially for length of two ommatidia, without interommatidial spicules. Antenna (Figure 6) with flagellomeres 2-8 elongate, subcylindrical or subconical, 9-12 slightly more elongate, 13 subcylindrical with apical nipple, constricted basally; antennal ratio $0.75-1.02$ (0.89, n=11). Palpus (Figure 7) pale brown, third segment elongate, with prominent basal
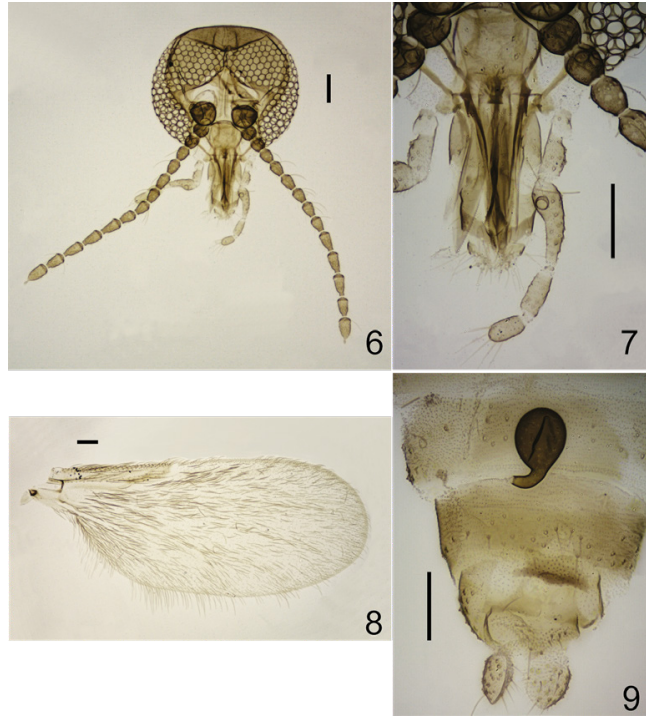

Figures 6-9. Forcipomyia (Synthyridomyia) murina (Winnertz). Female. 6: Head. 7: Palpus. 8: Wing. 9: Genital sclerotization and spermatheca. Scale bars: $0.05 \mathrm{~mm}$.
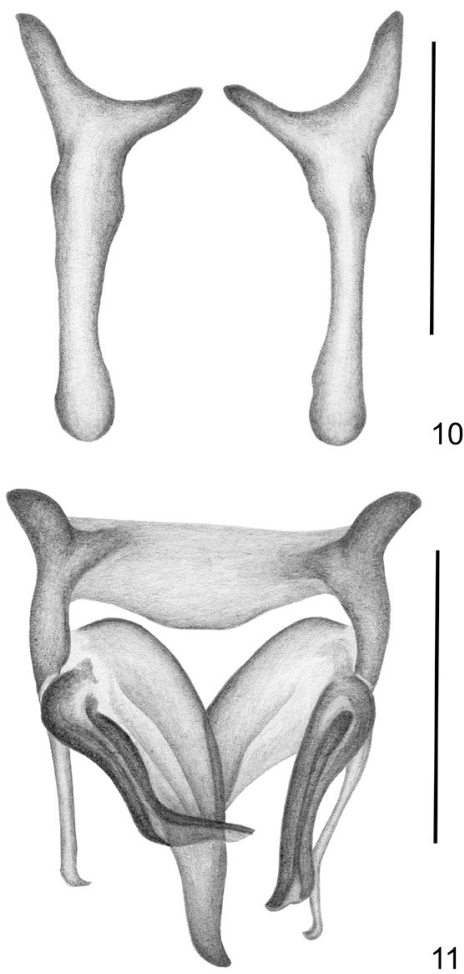

11

Figures 10-11. Forcipomyia (Synthyridomyia) murina (Winnertz). Male. 10: Parameres. 11: Aedeagus. Scale bars: $0.05 \mathrm{~mm}$. 
swelling bearing rounded pit; segments 4, 5 separate, 5 shorter than 4; palpal ratio 2.50-3.60 $(2.92, n=12)$. Mandible with 22-27 $(26, n=12)$ minute teeth.

Thorax brown; scutellum paler, with 12 large, 6 smaller setae. Legs light brown; prothoracic tarsal ratio $2.10-2.67(2.44, \mathrm{n}=11)$; mesothoracic tarsal ratio $2.11-2.45(2.36, \mathrm{n}=11)$, metathoracic tarsal ratio $2.00-2.50(2.27, \mathrm{n}=11)$; tarsal claws well developed, curved. Wing (Figure 8) membrane pale, covered with macrotrichia; base of $\mathrm{M}_{2}$ not visible; 1 st radial cell obliterated, 2nd radial cell well developed; cubital fork distal to level of apex of costa; wing length $0.74-1.06$ $(0.89, \mathrm{n}=12) \mathrm{mm}$, breadth $0.32-0.45(0.38, \mathrm{n}=12)$ $\mathrm{mm}$; costal ratio $0.34-0.40(0.37, \mathrm{n}=12)$. Halter whitish.

Abdomen (Figure 9) pale brown. Sternite 8 with transversal, dark brown ribbon. Genital plate of sternite 9 lightly sclerotized, subquadrangular with rounded lumen. Spermatheca globose with prominent oblique neck, the globose portion measuring $40-50(44, n=12) \mu m$ of diameter, neck $14-30(22, n=12) \mu m$ long.

Types. Ceratopogon murinus: Two syntypes from Germany are in the British Museum, and other Winnertz material presumably is in the Vienna Museum, Bonn Museum and Senckenberg Museum (Dow \& Wirth, 1972).

Forcipomyia calchaqui: Holotype female, Argentina, Salta, Cafayate, $26^{\circ} 3^{\prime} 54.14^{\prime \prime}$ S, 655'21.99" W, 17-VIII-1980, G. Spinelli, at light (MLPA, examined).

Forcipomyia soibelzoni: Holotype female, Argentina, Río Negro, meseta de Somuncurá, Chipauquil, vertiente arroyo Valcheta, 40 $58^{\prime} 25^{\prime \prime}$ S, 66³9'14.7" W, 630 m, 28-XI-1995, G. Spinelli, Shannon trap (MLPA, examined).

Other specimens examined. Argentina, Salta, Cachi, 257'5.72" S, 66 9'47.78" W, 18-I-2000, G. Spinelli, 1 female, at light; Salta, Cafayate, motel ACA, 263'54.14"S, 6558'21.99" W, 27III-2005, G. Spinelli, 2 females, at light; same data except 28-III-2005, G. Spinelli, 1 male, 4 females; La Rioja, río Miranda at national route 40, 2920'50.4" S, 67042'12.8" W, 1590 m, 17/18XI-2007, G. Spinelli, 1 female, CDC light trap;

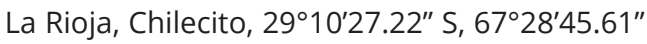
W, 29-IX-1989, G. Spinelli, at light; Santiago del Estero, Añatuya, $28^{\circ} 27^{\prime} 38.08^{\prime \prime} \mathrm{S}, 62^{\circ} 50^{\prime} 3.71^{\prime \prime}$
W, XII-1998, D. Carpintero, 2 females, at light; Córdoba, paraje Las Jarillas, río San Antonio, $31^{\circ} 32^{\prime} 02.8^{\prime \prime} \mathrm{S}, 64^{\circ} 33^{\prime} 01.7^{\prime \prime} \mathrm{W}, 820 \mathrm{~m}, 25-\mathrm{XI}-2007$, G. Spinelli, 1 female, Malaise trap; Córdoba, río Suquía at arroyo Huerta Grande, $31^{\circ} 05^{\prime} 00.6^{\prime \prime} \mathrm{S}$, 6430'05.2" W, 934 m, 21-X-2008, P. Marino, 1 female, sweeping; Corrientes, Colonia Pellegrini,

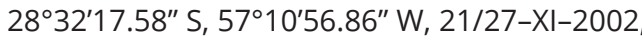
M. Coscarón, 1 male, Malaise trap; Buenos Aires, Alberti, 351'28.63" S, 60¹5'36.92" W, 15-I-1999, G. Spinelli, 1 female, sweeping; same data except 25-XII-1999, 1 male.

Distribution. Widely spread in the Holarctic and Afrotropical regions, reported also from the Oriental region (Taiwan). Records in the Neotropical region are those from Argentina, in Salta, La Rioja, Santiago del Estero, Córdoba, Corrientes, Buenos Aires and Río Negro provinces.

Taxonomic discussion. Although the specimens from Argentina that were previously identified as $F$. calchaqui, show some slight meristic differences with respect to the available descriptions of $F$. murina from the Holarctic region, such as shorter costal ratio and longer fifth palpal segment, the great resemblance of the male genitalia leaves little doubt about that the Holarctic and Neotropical specimens represent a single species, supporting thus the proposed synonymy. Besides, a close examination of the female holotype of $F$. soibelzoni revealed that it is identical to the female holotype of F. calchaqui, and therefore it has to be considered also a junior synonym of $F$. murina.

All diagnostic characters distinguishing males and females of $F$. murina from the other Neotropical species of the subgenus Synthyridomyia may be found in the key provided above.

Three Oriental species of the subgenus, $F$. (S.) longitarsis Tokunaga, 1940, F. (S.) contigoa Liu \& Yu, in Yu et al., 2005 and $F$. (S.) xsiangshanensis Yu, Liu \& Chen, in Liu et al., 2009 are very similar to $F$. murina. In $F$. longitarsis the aedeagal basal bridge is distinctly narrower with its distal margin straight, the lateral arms are directed mesally, and the slender sclerite that articulates from the caudal margin of the lateral arm is directed mesally. In $F$. contiguous the aedeagal basal 
bridge is also distinctly narrower with its distal margin straight, the distomesal portion of the aedeagus is represented by a cylindrical process with blunt tip and the basimedian processes of parameres are straight, not angular. Finally, the aedeagal posteroventrally curved plate has a truncate tip in F. xsiangshanensis.

\section{REFERENCES}

Alwin, A. \& Szadziewski, R. (2013). Biting midges of the subgenus Trichohelea of Forcipomyia in Poland, with keys for the determination of Polish subgenera (Diptera: Ceratopogonidae). Polish Journal of Entomology, 82: 113-126.

Alwin-Kownacka, A., Szadziewski, R. \& Szwedo, J. (2016). Biting midges of the subfamily Forcipomyiinae (Diptera: Ceratopogonidae) from the Middle East, with keys and descriptions of new species. Zootaxa, 4173(4): 351-378.

Boorman, J. \& van Harten, A. (2002). Some Ceratopogonidae (Insecta: Diptera) from the Arabian Peninsula, with particular reference to the Republic of Yemen. Fauna of Arabia, 19: 427-462.

Borkent, A. (2016). World species of biting midges (Diptera: Ceratopogonidae). Available from: http://www.inhs.uiuc.edu/ research/FLYTREE/CeratopogonidaeCatalog. pdf. (accessed: 18-01-2018).

Borkent, A. \& Spinelli, G. R. (2007). Neotropical Ceratopogonidae (Diptera: Insecta). In: Adis, J., Arias, J. R., Rueda-Delgado, G. \& Wantzen, K. M. (Eds.). Aquatic Biodiversity in Latin America (ABLA). Vol. 4. Moscow: Pensoft.

Borkent, A., Spinelli, G. R. \& Grogan, W. L., Jr. (2009). Ceratopogonidae (biting midges, purrujas). Chapter 29. In: Brown, B., Borkent, A., Cumming, J. M., Wood, D. M., Woodley, N. E. \& Zumbado, M. A. (Eds.). Manual of Central American Diptera. Volume 1. (p. 407-435). Ottawa: NRC Research Press.

Dow, M. I. \& Wirth, W. W. (1972). Studies on the genus Forcipomyia, 2. The Nearctic species of the subgenera Thyridomyia and Synthyridomyia (Diptera: Ceratopogonidae). Annals of the Entomological Society of America, 65(1): 177-201.

Goetghebuer, M. (1950). Ceratopogonidae et Chironomidae nouveaux ou peu connus d'Europe (Quatorzieme note). Bulletin Institut Royal des Sciences Naturelles de Belgique, 26: 1-15.

Kieffer, J. J. (1919). Chironomides d'Europe conservés au Musée National Hongrois de Budapest. Annales Musei Nationalis Hungarici, 17: 1-160.

Kieffer, J. J. (1923). Ceratopogonines recueillis au Sahara Constantinois. Archives de I'Institut Pasteur Algérie, 1: 654-683.

Kieffer, J. J. (1924). Quelques nouveaux chironomides piqueurs de l'Europe centrale. Archives de l'Institut Pasteur Algérie, 2: 391-408.

Kieffer, J. J. (1925). Chironomides d'Egypte (Dipt.). Bulletin de la Société Royale Entomologique d'Egypte, 8: 244-313.

Liu, Y.-Q., Chen, H.-Y. \& Yu, Y.-X. (2009). A key of Forciomyia [sic] (Synthyridomyia) with discription [sic] of a new species from China (Diptera: Ceratopogonidae) [in Chinese, English summary]. Sichuan Journal of Zoology, 28: 521-523.

Macfie, J. W. S. (1943). Ceratopogonidae (Diptera) from Egypt. Proceedings of the Royal Entomological Society of London, 12: 145-159.

Marino, P. I. y Spinelli, G. R. (2001). Los subgéneros de Forcipomyia, Thyridomyia y Synthyridomyia en la Patagonia argentina, con la descripción de $F$. (S.) soibelzoni sp. $n$. (Diptera: Ceratopogonidae). Neotrópica, 47: 13-16.

Muzón J., Spinelli, G. R., Pessacq, P., von Ellenrieder, N., Estévez, A. L., Marino, P. I., Perez Goodwyn, P.J., Angrisano, E. B., Díaz, F., Fernández, L. A., Mazzucconi, S., Rossi, G. C. \& Salomón, O. D. (2005). Insectos acuáticos de la Meseta del Somuncurá, Patagonia, Argentina. Inventario preliminar. Revista de la Sociedad Entomológica Argentina, 64: 47-67.

Remm, H. (1980). New species of the family Ceratopogonidae (Diptera) from the Middle Asia. Tartu Riikliku Ulikooli Toimetised, 516: 85-128.

Remm, H. (1981). New synonyms and new names of the Palaearctic Ceratopogonidae (Diptera). Eesti NSV Teaduste Akadeemia Toimetised, 30: 27-32.

Saunders, L. G. (1957). Revision of the genus Forcipomyia based on characters of all stages (Diptera, Ceratopogonidae). Canadian Journal 
of Zoology, 34: 657-705 [1956].

Spinelli, G. R. \& Marino, P. I. (1997). Two new species of the subgenus Thyridomyia of Forcipomyia from Argentina and new records of F. (Synthyridomyia) sanctaeclarae (Diptera: Ceratopogonidae). Transactions of the American Entomological Society, 123: 187-190.

Spinelli, G. R., Marino, P. I. \& Gaddi, A. (2010). New records of biting midges from Argentina and Chile (Diptera: Ceratopogonidae). Revista de la Sociedad Entomológica Argentina, 69: 127-132.

Szadziewski, R. (1983). Ceratopogonidae (Diptera) from Algeria. II. New species, new records and new synonymy in the genus Forcipomyia Meig. Polish Journal of Entomology, 53: 363-384.

Szadziewski, R. (1986). Redescriptions and notes on some Ceratopogonidae (Diptera). Polish Journal of Entomology, 56: 3-103.
Szadziewski, R., Gwizdalska-Kentzer, M. \& Giłka, W. (2011). Order Diptera, family Ceratopogonidae. In: H.H. Sheikh Tahnoon Bin Zayed Al Nahyan (patron), van Harten A. (Ed.). Arthropod fauna of the United Arab Emirates. Volume 4. (pp. 636-653). Dar Al Ummah: UAE.

Tokunaga, M. (1940). Biting midges from Japan and neighbouring countries, including Micronesian Islands, Manchuria, North China and Mongolia (Diptera, Ceratopogonidae). Tenthredo, 3: 58-100.

Winnertz, J. (1852). Beitrag zur Kenntniss der Gattung Ceratopogon Meigen. Linnaea Entomologica, 6: 1-80.

Yu, Y.-X., Liu, J.-H., Liu, G.-P., Liu, Z.-J., Hao, B.-S., Yan, G. \& Zhao, T.-S. (2005). Ceratopogonidae of China, Insecta, Diptera [in Chinese]. Volumes 1-2. Beijing: Military Medical Science Press. 